\title{
KONSTRUKSI KAUSATIF ANALITIK BAHASA KEMAK
}

\author{
I Wayan Budiarta \\ STIBA Mentari Kupang \\ budy4rt4@yahoo.com
}

\begin{abstract}
ABSTRAK
Artikel ini merupakan bagian dari disertasi penulis. Judul penelitian ini adalah Konstruksi Kausatif Analitik Bahasa Kemak. Artikel ini bertujuan untuk mengungkap bagaimana konstruksi kausatif analitik bahasa Kemak di bentuk. Data penelitian ini diperoleh melalui metode linguistik lapangan yang mencakup elisitasi langsung, perekaman, dan pengecekan elisitasi. Lebih lanjut, instrumen penelitian yang digunakan dalam penelitian ini adalah daftar tanyaan. Di samping pendistribusian daftar tanyaan, data penelitian ini juga dikumpulkan melalui perekaman Data rekaman yang diambil berupa data dalam bentuk teks yang bersumber dari cerita-cerita ataupun percakapan informan atau di antara penutur bahasa Kemak. Metode distribusional (agih) diterapkan dalam menganalisis data penelitian berdasarkan permasalahan yang dibahas dalam artikel ini. Hasil analisis data penelitian ini disajikan dengan menggunakan metode infromal berupa penjelasan atau paparan dengan menggunakan kata-kata biasa atau bahasa verbal. Hasil analisis data menunjukkan bahwa konstruksi kausatif analitik bahasa Kemak dibentuk oleh verba kausatif tau 'buat' dengan predikat yang ditempati oleh verba intransitif, verba transitif, dan adjektiva. Di samping konstruksi kausatif analitik yang dibangun oleh verba kausatif tau 'buat', konstruksi kausatif analitik bahasa Kemak dapat pula dibentuk oleh verba kausatif laka 'suruh' yang hanya dapat diikuti oleh verba intransitif dan verba transitif. Konstruksi kausatif analitik dengan predikat verba intransitif dan verba transitif memiliki bentuk alternasi. Bentuk alternasi konstruksi kausatif analitik ini disebabkan adanya perbedaan posisi objek yang bisa hadir setelah verba kausatif tau 'buat' dan laka 'suruh' atau setelah verba intranstif dan verba transitif yang menempati posisi sebagai predikat.
\end{abstract}

Kata kunci: bahasa Kemak, kausatif analitik, verba kausatif

\section{ABSTRACT}

This article is part of the writer's dissertation. The title of this article is Analytic Causative Construction of Kemak Language. This article is aimed to find out how the analytic causative construction of Kemak language is constructed. The data of this research is obtained through field lingusitics method which covers direct elicitation, recording, and elicitation checking. Moreover, the research instrument which is used in this research is questionairre. Besides delivering questionairre, the data of this research is also taken through recording, The data recording which is taken is in the form of text whether it derived from the strories or the conversations from the informants or among the speaker of the language, Distributional method is applied in analyzing the data based on the problem discussed. The result of data analysis is presented by using informal method in the form of explanation by using ordinary words or verbal language. The result of analysis shows that analytic causative construction of Kemak langauge is constructed by causative verb of tau 'make' with the predicate which is filled by intransitive verb, transitive verb, and adjective. Besides analytic causative construction which is built by causative verb tau 'make', analytic causative construction of Kemak language can also be built by causative verb laka 'ask to' which can only be followed by intranstive and transitive verb. Analytic causative of Kemak langauge with intranstive and transtive verbs predicates have alternation structure. The alternation structure of analytic causatives due to the different

\section{PENDAHULUAN}

Terdapat empat bahasa yang digunakan oleh masyarakat di Kabupaten
Belu, yaitu bahasa Dawan, bahasa Tetun, bahasa Bunak, dan bahasa Kemak. Jika dibandingkan dari keempat bahasa tersebut, 
bahasa Kemak (BKm) memiliki jumlah penutur yang jauh lebih sedikit dibandingkan dengan penutur bahasa lainnya di Kabupaten Belu. Data menunjukkan bahwa penutur BKm berjumlah sekitar 3.000 orang. Dalam kehidupan masyarakat Belu, Bahasa Kemak merupakan bahasa yang dituturkan oleh suku Kemak yang berada di Desa Umaklaram dan Desa Sadi, Kecama$\tan$ Tasifeto Timur Kabupaten Belu.

Dari keempat bahasa tersebut, bahasa Dawan, bahasa Tetun, dan bahasa Kemak digolongkan ke dalam kelompok bahasa Austronesia, sementara bahasa Bunak digolongkan ke dalam kelompok bahasa NonAustronesia (Klamer dalam Pieter Muysken, 2008: 112--113). Jika dilihat dari pola kanonik keempat bahasa tersebut, bahasa Dawan, bahasa Tetun, dan bahasa Kemak memiliki pola kanonik SVO. sementara bahasa Bunak memiliki pola SOV. Dari pola kanonik tersebut dapat dilihat bahwa subjek kalimat BKm menempati posisi praverbal dan objek menempati posisi posverbal. Dengan demikian, jelaslah bahwa predikat (verba) bahasa Kemak didahului oleh subjek dan dikuti oleh objek. Jika melihat unsur yang membentuk kalimat, kalimat BKm dibangun oleh nomina atau frasa nomina yang mengisi posisi subjek dan objek, sementara predikat bisa ditempati oleh verba, nomina, adjektiva, numerali, dan frasa preposisional. Kon- struksi kalimat ini dapat dijumpai hampir pada seluruh bahasa di dunia.

Menarik untuk ditelaah terkait dengan konstruksi kalimat BKm yang dibangun dengan predikat verbal. Hal ini disebabkan karena hanya kalimat dengan predikat verbal yang memiliki mekanisme perubahan valensi. Di samping itu, istilah valensi sangat berkaitan erat dengan verba karena predikat yang diisi oleh verba yang mampu menaikkan atau menurunkan valensinya

Mekanisme perubahan valensi verba BKm mencakup pembahasan tentang konstruksi verbal, yaitu konstruksi kausatif, aplikatif, dan resultatif. Tulisan ini hanya memfokuskan untuk mengkaji konstruksi kausatif analitik BKm. Seperti diketahui bahwa konstruksi kausatif berdasarkan parameter formal (morfosintaksis) terdiri atas kausatif leksikal, kausatif morfologis, dan kausatif analitik. Kausatif leksikal tidak dibicarakan pada tulisan ini karena seluruh bahasa di dunia memiliki tipe kausatif ini. Hal ini disebabkan bahwa bahasa-bahasa di dunia memiliki leksikal atau verba yang secara alami telah mengandung makna kausatif. Sementara, kausatif morfologis tidak dibicarakan dalam tulisan ini karena berdasarkan hasil penelitian penulis sebelumnya menunjukkan bahwa BKm tidak memiliki afiks yang mampu menaikan ataupun menurunkan valensi verbanya se- 
hingga tidak ditemukan adanya kausatif morfologis.

Berdasarkan uraian tersebut di atas, artikel ini mencoba untuk menjawab dua pertanyaan, yaitu bagaimanakah konstruksi kausatif BKm dibentuk. Pertanyaan tersebut yang mendasari tulisan ini dibuat sehingga dapat memberikan pengetahuan terutama terkait dengan konstruksi kausatif analitik BKm yang nantinya diharapkan mampu memperkaya khazanah kelinguistikan di Indonesia.

\section{KONSEP DAN KERANGKA TEORI KONSEP VALENSI}

Istilah valensi dalam linguistik merujuk pada kemampuan verba, yang menempati unsur predikat sebuah klausa/kalimat untuk mengikat argumen. Valensi lebih mengacu pada jumlah argumen yang dibutuhkan oleh verba yang menempati posisi predikat. Aisen dalam Hopper and Thompson (ed) (1982:8) mengungkapkan bahwa valensi digunakan untuk merujuk ke jumlah argumen nominal dalam sebuah klausa pada tataran apa saja.

\section{KONSEP KAUSATIF}

Konsep tentang konstruksi kausatif diungkapkan oleh Goddard (1998: 266) yang menyatakan bahwa konstruksi kausatif merupakan satu ungkapan yang di dalamnya mengandung sebuah peristiwa yang disebabkan oleh perbuatan seseorang atau karena sesuatu terjadi. Konsep tentang kausatif juga diberikan oleh Artawa (2004:48) yang menyatakan bahwa hampir setiap bahasa mempunyai caranya tersendiri untuk membentuk atau mengungkapkan konstruksi kausatif. Secara umum, konstruksi kausatif menggambarkan mikro atau peristiwa yang terdiri atas (1) peristiwa penyebab (causee) yang menyebabkan suatu peristiwa terjadi (causing event) dan (2) peristiwa yang terjadi atau akibat yang timbul (caused) yang disebabkan oleh tindakan tersebab (causee) (Shibatani 1976: 239, Comrie, 1985:330, dan Song, 2001:253).

\section{KONSEP KAUSATIF ANALITIK}

Kausatif analitik merupakan konstruksi kausatif yang memiliki predikat yang mengungkapkan sebab-akibat, penyebab diungkapkan oleh kata terpisah dari kata yang menunjukkan yang disebabkan (akibat) Comrie (1981: 158--160; 1989:165--171).

\section{KERANGKA TEORI}

Tipe-tipe konstruksi kausatif yang dimiliki oleh setiap bahasa berbeda satu dengan yang lainnya. Ada bahasa yang memiliki ketiga tipe konstruksi (kausatif leksiskal, kausatif morfologis dan kausatif analitik) dan ada juga bahasa yang hanya memiliki dua tipe konstruksi kausatif; kausatif leksikal dan kausatif analitik. Ba- 
hasa yang memiliki ketiga tipe konstruksi pada umumnya merupakan bahasa yang bertipe aglutinasi karena bahasa bertipe ini mempunyai afiks yang dapat dilekatkan pada verba yang berfungsi menaikkan atau menurunkan valensi verba. Sementara, bahasa yang hanya memiliki dua tipe kausatif merupakan bahasa yang bertipe isolasi karena bahasa tersebut pada umumnya tidak memiliki afiks yang berfungsi untuk menaikkan atau menurunkan valensi verba.

Goddard (1998: 266) menjelaskan bahwa konstruksi kausatif merupakan satu ungkapan yang di dalamnya mengandung sebuah peristiwa yang disebabkan oleh perbuatan seseorang atau karena sesuatu terjadi. Pendapat tentang pengkausatifan atau konstruksi kausatif juga dikemukakan Artawa (2004:48), yang mengungkapkan bahwa hampir setiap bahasa memiliki cara yang khas untuk membentuk atau mengungkapkan konstruksi kausatif. Pada umumnya, konstruksi kausatif merupakan konstruksi yang menggambarkan sebuah situasi makro-kompleks yang mengandung dua situasi mikro atau peristiwa yang terdiri atas (1) peristiwa penyebab (causee) yang menyebabkan suatu peristiwa terjadi (causing event) dan (2) peristiwa yang terjadi atau akibat yang timbul (caused) yang disebabkan oleh tindakan tersebab (causee) (Shibatani 1976: 239, Comrie, 1985:330, dan Song, 2001:253).
Fakta menunjukkan bahwa setiap bahasa memiliki konstruksi gramatikal yang berbeda satu dengan lainnya untuk mengungkapkan konstruksi kausatif. Namun demikian, secara lintas bahasa kesetaraan konstruksi kausatif dapat diungkapkan secara sintaksis dan analitis.

Artawa (1998: 32) menyatakan bahwa satu perbedaan sintaksis utama antara konstruksi bukan kausatif dan konstruksi kausatif adalah terletak pada penaikan valensi verba pada konstruksi kausatif. Kajian tentang perubahan valensi verba yang disebabkan oleh pengkausatifan menitikberatkan pada perbedaan valensi verbaverba dasar nonkausatif yang meliputi verba intransitif (tidak terdapat OL), verba ekatransitif (terdapat OL, tetapi tidak terdapat OTL), dan verba dwitransitif (terdapat Ol dan OTL). Keterkaitan hubungan antara konstruksi kausatif dan konstruksi nonkausatif dijelaskan melalui hierarki relasi gramatikal subjek > objek langsung $>$ objek tak langung $>$ objek oblik. Dalam hierarki relasi gramatikal tersebut dijelaskan bahwa tersebab (causee) menempati posisi tertinggi, yaitu posisi paling kiri yang merupakan posisi argumen kausatif yang belum terisi (Comrie, 1985:342).

Perubahan valensi verba dasar nonkausatif menjadi verba kausatif, pada prinsipnya merupakan penambahan agen ke 
Tabel 1: Perubahan Valensi Verba Dasar NonKuasatif Menjadi Verba Kausatif

\begin{tabular}{|c|c|c|}
\hline Tipe Klausa & Verba Dasar Nonkausatif & Verba Kausatif \\
\hline \multirow[t]{2}{*}{ Intransitif } & SUBJ - & SUBJ \\
\hline & & $\rightarrow \mathrm{OL}$ \\
\hline \multirow[t]{3}{*}{ Ekatransitif } & SUBJ & SUBJ \\
\hline & $\mathrm{OL}^{-}$ & $\rightarrow$ OL \\
\hline & & $\rightarrow$ OTL \\
\hline \multirow[t]{4}{*}{ Dwitransitif } & SUBJ & SUBJ \\
\hline & $\mathrm{OL}^{-}$ & $\longrightarrow \mathrm{OL}$ \\
\hline & $\mathrm{OTL}^{-}$ & $\longrightarrow \mathrm{OTL}$ \\
\hline & & $\rightarrow \mathrm{OBL}$ \\
\hline
\end{tabular}

Pendapat mengenai pengkausatifan atau konstruksi kausatif juga diungkapkan oleh Arka (1993). Mengacu pada pendapat Shibatani (1976), Comrie (1981 dan 1989), Spencer (1991), dan Jackenkoft (1991), Arka (1993:8) mengungkapkan bahwa konstruksi kausatif dibedakan menjadi dua, yaitu kausatif perifrastik/analitik dan kausatif morfologis/leksikal. Kausatif perifrastik/analitik merupakan konstruksi biklausal. Adapun konstruki kausatif merfologis/leksikal merupakan konstruksi monoklausal. Kausatif morfologis/leksikal disebut juga sebagai kausatif langsung. Adapun pembagian konstruksi kausatif yang dikemukakan oleh Arka (1993:8) didasarkan atas jumlah klausa yang terdapat dalam sebuah konstruksi kausatif. Perbedaan pembagian kausatif menurut Arka (1993:8) dan Comrie (1981: 158-160; 1989:165--171), pada prinsipnya tidak bertentangan satu sama lain.

Pendapat yang berbeda tentang pengkausatifan atau konstruksi kausatif diungkapkan oleh Alsina dan Joshi (1991) (seperti dikutip dari Jufrizal 2004:198200). Alsina dan Joshi (1991) mengusulkan pendekatan struktur argumen terhadap pengkausatifan. Prinsip teori yang dikemukakan oleh Alsina dan Joshi (1991) tidak berkenaan dengan fungsi gramatikal, tetapi berkenaan dengan struktur argumen. Teori ini mengungkapkan bahwa argumenargumen diurutkan menurut Hierarki Tematik Universal (Universal Theumatic Hierarchy), yakni agen lebih tinggi daripada resipien (penerima) yang pada gilirannya memiliki posisi lebih tinggi dari pada pasien dan tema.

Pendapat yang dikemukakan oleh Alsina dan Joshi (1991) didasarkan pada kelemahan pendekatan kausatif morfologis 
yang semata-mata didasarkan pada prinsip sintaksis. Mereka menilai bahwa prinsip sintaksis gagal mengetahui rentangan penuh variasi sintaksis dan tidak mampu mengaitkan variasi sintaksis dengan variasi semantis yang mendasarinya. Lebih jauh, mereka menegaskan bahwa prinsip pemetaan memiliki peranan penting untuk menurunkan realisasi morfosintaksis yang benar dari terakibat. Mereka berpendapat bahwa kausatif morfologis dibentuk berdasarkan penggabungan struktur argumen dua prredikat, yaitu predikat dasar dan morfem kausatif yang membentuk struktur sintaksis klausa tunggal (monoklausal).

Seperti dijelaskan pada bagian sebelumnya bahwa secara tipologis, BKm digolongkan ke dalam kelompok bahasa isolasi karena minimnya afiks yang ditemukan dalam BKm. Tidak adanya afiks yang berfungsi untuk mengubah konstruksi nonkausatif menjadi konstruksi kausatif berdampak pada tidak ditemukannya pengkausatifan atau konstruksi kausatif morfologis dalam BKm. Dengan demikian, pembahasan pengkausatifan atau konstruksi kausatif dalam BKm berdasarkan parameter formal (morfosintaksis) hanya memfokuskan pembahasan kausatif analitik seperti yang telah diuraikan pada awal tulisan ini. Pembahasan kausatif analitik merupakan fokus pada tulisan ini.

\section{PEMBAHASAN}

KONSTRUKSI KAUSATIF ANALITIK BAHASA KEMAK

Berdasarkan parameter formal (morfosintaksis), Comrie (1981: 158--160; 1989:165--171) menyatakan bahwa konstruksi kausatif dibedakan menjadi tiga, yaitu kausatif analitik, kausatif morfologis, dan kausatif leksikal. Dari ketiga konstruksi kausatif yang dikemukan oleh Comrie (1981: 158--160; 1989:165--171) tersebut, BKm hanya memiliki konstruksi kausatif leksikal dan konstruksi kausatif analitik. Ketiadaan konstruksi kausatif morfologis disebakan karena BKm minimnya afiks yang ditemukan dalam BKm.

Sesuai dengan fokus penelitian ini, maka penlitian ini akan menitikberatkan pada upaya untuk mengungkap konstruksi analitik BKm, Namun demikian, untuk memberikan gambaran yang menyeluruh tentang konstuksi kausatif BKm berdasarkan parameter formal (morfosintaksis), maka pembahasan ini akan diawali dengan menjelaskan tentang kausatif leksikal BKm.

Kausatif leksikal merupakan konstruksi kausatif yang ditunjukkan melalui verba yang saling berhubungan dalam predikat nonkausatif tetapi tidak berkaitan secara morfologis dengan predikat kausatif, hubungan predikat yang mengungkapkan akibat dan yang mengungkapkan sebab tidak sistematis, hanya diungkapkan dengan 
leksikal yang memiliki makna sebabakibat, seperti kata die 'mati' dan kill 'bunuh' dalam bahasa Inggris. Dalam bahasa Indonesia dapat dicontohkan dengan verba kausatif, seperti mati/bunuh dan tumbang/tebang. Penerapan kedua verba mati/ bunuh dan tumbang/tebang tersebut tersaji pada proposisi saya membunuh anjing itu dan ayah menebang pohon itu memiliki sinonim saya menyebabkan anjing itu mati dan ayah menyebabkan pohon itu tumbang. Kausatif leksikal pada kedua klausa tersebut menunjukkan bahwa tidak terdapat hubungan yang sistematis antara verba bunuh dan tebang sebagai penyebab dari mati dan tumbang.

Pengkausatifan atau konstruksi kausatif $\mathrm{BKm}$ umumnya menggunakan verba ekatransitif. Verba ekatransitif BKm sebagian besar mengandung makna kausatif, seperti verba nua 'bunuh', иnu 'tikam', leli 'tebang', lobu 'potong', adi 'asah', demi 'rendam', sunu 'bakar', dan poa 'belah'. Penerapan setiap verba ekatransitif pada konstruksi kausatif BKm tersaji pada klausa-klausa berikut.

Atmas senua nua ama-ng
bibu
orang $\begin{aligned} & \text { DEF bunuh ayah-Lig } \\ & \text { kambing }\end{aligned}$
'Orang itu membunuh kambing ayah'
senua unu atmas
senua
laki-laki DEF tikam orang DEF
'Laki-laki itu menikam orang itu'

Au leli ai senua

1TG tebang pohon DEF

'Saya menebang pohon itu'

Ama lobu tali senua
ayah potong tali DEF
'Ayah memotong tali itu'
Ua adi di'ir anag
3TG asah pisau
'Dia mengasah pisau'

$\begin{array}{lll}\text { Ina demi } & \text { au-ng } & \text { baru } \\ \text { ibu rendam } & \text { 1TG-Lig } & \text { baju }\end{array}$

'Ibu merendam baju saya'

Roma sunu uma senua
3JM bakar rumah DEF
'Mereka membakar rumah itu'
Ita poa batu senua
1JM belah batu DEF
'Kita membelah batu itu'

Klausa (1)-(8) merupakan konstruksi kausatif BKm. Dapat dijelaskan bahwa setiap verba yang membangun klausa di atas mengandung makna kausatif. Verba nua 'bunuh' yang membangun klausa (1) mengandung makna kausatif. Klausa (1) menggambarkan bahwa argumen atmas senua 'orang itu' yang secara sintaksis merupakan subjek gramatikal dan sekaligus secara semantis merupakan agen, melakukan suatu tindakan, yaitu membunuh yang terungkap melalui verba nua terhadap argumen amang bibu 'kambing ayah' yang secara sintaksis merupakan objek dan secara semantis merupakan pasien sehingga menyebabkan objek/pasien tersebut terbunuh/mati.

Hal yang sama juga terjadi pada 
konstruksi kausatif pada klausa (2). Argumen mane senua 'laki-laki itu' yang secara sintaksis merupakan subjek gramatikal dan sekaligus secara semantis merupakan agen, melakukan suatu tindakan, yaitu menusuk argumen atmas senua 'orang itu' yang secara sintaksis merupakan objek dan secara semantis merupakan pasien melakukan suatu tindakan yang tercermin pada verba ипи 'tusuk' sehingga menyebabkan objek/pasien tersebut tertusuk. Sama halnya pada klausa (1) dan (2), konstruksi kausatif pada klausa (3) menggambarkan bahwa argumen au 'saya' melakukan sesuatu, yaitu menebang argumen ai senua 'pohon itu' sehingga menyebabkan argumen tersebut tertebang/ tumbang. Konstruksi kausatif pada klausa (4) menggambarkan bahwa argumen ama 'ayah' melakukan suatu tindakan yang tercermin oleh verba lobu 'potong' sehingga menyebabkan tali senua 'tali itu terpotong/putus.

Selanjutnya berturut-turut verba adi 'asah' (klausa (5), demi 'rendam' (klausa 6), sunu 'bakar' (klausa 7), dan poa 'belah' (klausa 8) menggambarkan suatu tindakan yang dilakukan oleh argumen $u a$ 'dia' (klausa 5), ina 'ibu' (klausa 6), roma 'mereka' (klausa 7), dan ita 'kita' (klausa (8) yang menyebabkan argumen di'ir anag 'pisau' menjadi terasah/tajam (klausa (5), argumen aung baru 'baju saya' menjadi terendam/basah (klausa 6), argumen uma senua 'rumah itu' menjadi terbakar/hangus (klausa 7), dan argumen batu senua 'batu itu' menjadi terbelah/pecah (klausa 8). Konstruksi kausatif pada klausa (1) - (8) merupakan konstruksi kausatif BKm yang dibangun oleh verba ekatransitif.

Lebih jauh verba-verba ekatransitif tersebut secara alami telah memiliki makna sebab-akibat. Selain verba-verba ekatransitif tersebut, salah satu keunikan terkait dengan konstruksi kausatif yang dimiliki oleh $\mathrm{BKm}$ adalah $\mathrm{BKm}$ memiliki bentuk verba ekatransitif dari verba intransitif, seperti verba pule 'mematahkan', pae 'memasukkan', tboa 'memecahkan, 'lape 'menaikkan', dan luida 'menurunkan'. Verba ekatransitif yang membangun konstruksi kausatif BKm tersebut memiliki bentuk verba intransitif tersendiri, yaitu teta 'patah', mola 'masuk', broe 'pecah', $d u$ 'naik', dan sae 'turun'. Klausa-klausa berikut menyajikan konstruksi kausatif BKm yang dibangun oleh verba ekatransitif yang memiliki bentuk verba intransitif tersendiri.

\begin{tabular}{|c|c|c|}
\hline$A u$ & $\begin{array}{l}\text { pule } \\
\text { no }\end{array}$ & $a u-n g$ \\
\hline $1 \mathrm{TG}$ & $\begin{array}{l}\text { mematahkan } \\
\text { gan-Lig }\end{array}$ & 1TG-Lig \\
\hline
\end{tabular}

$\begin{array}{llll}\text { Ali pae } & \text { ika de } & \text { ember } \\ \text { Adik } & \text { memasukkan } & \text { ikan } & \text { Prep } \\ & \text { ember }\end{array}$

'Adik memasukkan ikan ke ember' 
Ina tboa

ura rae

Ibu memecahkan periuk tanah

'Ibu memecahkan periuk tanah'

\begin{tabular}{llll}
\multicolumn{2}{c}{ Atmas senua } & lape & bea \\
\multirow{2}{*}{ Orang } & dase & holang & \\
& DEF & menaikkan & air \\
& Prep & sungai &
\end{tabular}

'Orang itu menaikkan air dari sungai'

$\begin{array}{lll}\text { Mane } & \text { senua } & \text { luida } \\ & \text { nua } & \text { senua } \\ \text { Laki-laki } & \text { DEF } & \text { menurunkan } \\ & \text { kelapa } & \text { DEF }\end{array}$

'Laki-laki itu menurunkan kelapa itu'

Klausa (9) -- (13) merupakan konstruksi kausatif leksikal yang dibangun oleh verba ekatransitif. Verba ekatransitif yang membangun konstruksi kausatif leksikal tersebut memiliki bentuk verba intransitif tersendiri. Lebih jauh, verbaverba ekatransitif yang membangun konstruksi kausatif leksikal di atas secara alami sudah mengandung makna sebab-akibat. Konstruksi kausatif leksikal pada klausa (9) -- (12) di atas menunjukkan bahwa tidak terdapat hubungan yang sistematis antara verba sebagai penyebab dari akibat yang ditimbulkan.

Uraian diatas telah menjelaskan secara singkat tentang kausatif leksikal. Seperti yang telah dijelaskan sebelumnya dan mengacu pada rumusan permasalahan tulisan ini yang menitikberatkan pada kausatif analitk, maka pembahasan berikutnya menguraikan tentang kausatif analitik BKm.
Kausatif analitik disebut juga kausatif perifrastik. Kausatif jenis ini merupakan konstruksi kausatif yang memiliki predikat yang mengungkapkan sebab-akibat, penyebab diungkapkan oleh kata terpisah dari kata yang menunjukkan yang disebabkan (akibat). Predikat dalam konstruksi kausatif analitik diwujudkan dalam predikat yang terpisah. Konstruksi kausatif analitik dalam BKm dicirikan dengan kehadiran verba yang bermakna kausatif tau 'buat'dan laka 'suruh'.

Verba tau 'buat' dan laka 'suruh' merupakan verba yang mengandung makna kausatif dalam BKm. Kedua verba tersebut dapat membangun konstruksi kausatif dalam BKm. Verba tau 'buat' pada konstruksi kausatif menempati posisi sebelum predikat yang diisi oleh verba yang tidak bermakna kausatif sehingga membentuk verba kompleks yang bermakna kausatif yang menunjukkan sebab-akibat. Penambahan verba tau 'buat' yang bernakna kausatif membawa dampak kepada peningkatan valensi karena adanya argumen baru yang hadir akibat dari penambahan verba yang bermakna kausatif tersebut.

Seperti telah diuraikan sebelumnya bahwa pada hakikatnya pengkausatifan merupakan proses peningkatan valensi dengan penambahan argumen agen/aktor yang sekaligus merupakan penyebab terjadinya sebuah peristiwa kausatif. Untuk 
membentuk konstruksi kausatif, verba tau 'buat' dalam BKm dapat diikuti oleh verba nonkausatif dalam bentuk verba intransitif dan verba transitif, Di samping dapat diikuti oleh kedua tipe verba tersebut, verba kausatif tau 'buat' juga dapat diikuti oleh adjektival. Berikut disajikan konstruksi kausatif analitik yang dibentuk dari verba kausatif tau 'buat' dan verba intransitif.

\section{a. Au la de isikola \\ 1TG pergi Prep sekolah \\ 'Saya pergi ke sekolah'}

\begin{tabular}{|c|c|c|}
\hline $\begin{array}{l}\text { b. } \\
d e\end{array}$ & Ama tau & $a u$ \\
\hline Prep & $\begin{array}{l}\text { ayah buat } \\
\text { sekolah }\end{array}$ & $1 \mathrm{TG}$ \\
\hline
\end{tabular}

ke sekolah'

$\begin{array}{llll}\text { c. Ama tau la au } \\ \text { de } & \text { isikola } \\ \text { ayah buat pergi } & \text { 1TG } \\ \text { Prep isikola } & & \end{array}$

ke sekolah'

Ayah membuat pergi saya

$$
\begin{aligned}
& \text { a. Au-ng ali-ng bue } \\
& \text { 1TG-Lig adik-Lig tidur } \\
& \text { 'Adik saya tidur' } \\
& \begin{array}{llll}
\text { b. } & \text { Ina } & \text { tau } & \text { au-ng } \\
\text { ali-ng } & \text { bue } & & \\
& \text { ibu } & \text { buat } & \text { 1TG-Lig }
\end{array} \\
& \text { adik-Lig tidur } \\
& \text { 'Ibu membuat adik saya } \\
& \text { c. Ina tau bue au-ng } \\
& \text { ali-ng } \\
& \text { ibu buat tidur 1TG- }
\end{aligned}
$$

Lig adik-Lig

'Ibu membuat tidur/ menidurkan adik saya'
a. Gelas senua mnahu
gelas DEF jatuh

'Gelas itu jatuh'

$\begin{array}{ll}\text { b. Busa senua tau } \\ \text { gelas } & \begin{array}{l}\text { senua mnahu } \\ \text { kucing DEF buat } \\ \text { gelas }\end{array} \\ & \begin{array}{l}\text { DEF jatuh } \\ \text { 'Kucing itu membuat gelas }\end{array}\end{array}$

itu jatuh'

b. Busa senua tau

mnahu gelas senua kucing DEF buat

jatuh gelas DEF

'Kucing itu membuat jatuh/

menjatuhkan gelas itu'

a. Hine senua plai
wanita DEF lari
'Wanita itu lari'

b. Asu botengsenua tau

hine senua plai

anjing besar DEF buat

wanita DEF lari itu lari'

'Anjing besar itu membuat wanita

c. Asu botengsenua tau

plai hine senua

anjing besar DEF buat

lari wanita DEF

'Anjing besar itu membuat

lari wanita itu'

a. Roma hali

3JM pulang

'Mereka pulang'

b. Ama tau roma hali

ayah buat 3JM pulang

'Ayah membuat mereka pulang'

c. Ama tau hali roma ayah buat pulang 3JM 'Ayah membuat pulang mereka' 
Klausa (14a) - (18a) merupakan konstruksi klausa yang dibangun oleh verba intransitif. Sementara, klausa (14 b dan c) (18 b dan c) adalah konstruksi kausatif analitik yang dibangun oleh verba kausatif tau 'buat' dan verba intransitif. Lebih jauh, konstruksi kausatif analitik (14b)-(18b) memiliki konstruksi yang berbeda dengan konstruksi kausatif analitik (14c)-(18c). Konstruksi kausatif analitik (14c) - (18c) merupakan konstruksi alternasi dari konstruksi kausatif analitik (14b) - (18b).

Namun, kedua konstruksi kausatif tersebut berterima secara gramatikal dalam BKm. Pada hakikatnya, konstruksi kausatif atau pengkausatifan yang mengubah klausa intransitif menjadi konstruksi kausatif analitik yang dibangun oleh verba kausatif tau 'buat' dengan verba intransitif, mengubah fungsi gramatikal subjek pada klausa intransitif, yaitu au 'saya' pada klausa (14a), aung aling 'adik saya' pada klausa (15a), gelas senua 'gelas itu' pada klausa (16a), hine senua 'wanita itu' pada klausa (17a), dan roma 'mereka' pada klausa (18a) menjadi fungsi gramatikal objek pada konstruksi kausatif analitik pada klausa (14b dan c) - (18b dan c). Berikut disajikan konstruksi kausatif analitik yang dibangun oleh verba kausatif tau 'buat' dengan verba transitif.
a. Au tana ai senua
1TG tanam pohon DEF
'Saya menanam pohon itu'

b. Ama tau au tana
ai senua
ayah buat 1TG tanam
pohon DEF
"Ayah membuat saya me-
nanam pohon itu'

'Ayah membuat saya me-

a. Ua ala si ahi

3TG beli daging babi

'Dia membeli daging babi'

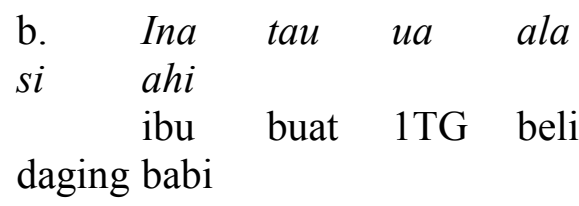

'Ibu membuat saya membeli

daging babi'

a. Mane senua ne osa
laki-laki DEF beri uang
'Laki-laki itu memberi uang'

b. Atmas senua tau mane $\begin{array}{llll}\text { senua } & \text { ne } & \text { osa } & \\ \text { orang } & \mathrm{DEF} & \text { buat laki- }\end{array}$

laki DEF beri uang

laki itu memberi uang'

'Orang itu membuat laki-

a. Ali leli ai enu senua adik tebang pohon kelapa DEF

'Adik menebang pohon kelapa itu'

b Au tau ali leli ai

1TG buat adik tebang pohon kelapa DEF

'Saya membuat adik menebang pohon kelapa itu'

a. Ina hoat batu senua

ibu angkat batu DEF

'Ibu mengangkat batu Itu

b. Ama tau ina hoat batu

ayah buat $\mathrm{Ib}$ angkat batu DEF

'Ayah membuat ibu mengngkat ba- 


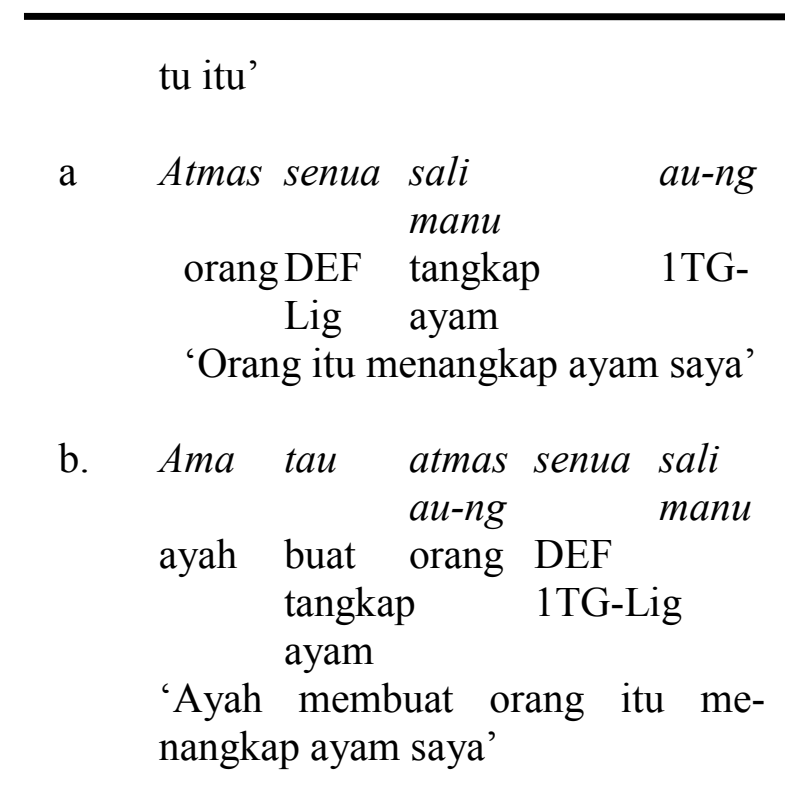

Klausa (19a)-(24a) adalah klausa yang dibangun oleh verba transitif dalam BKm. Verba transitif pada klausa tersebut dapat pula membentuk konstruksi kausatif analitik apabila verba transitif tersebut didahului oleh verba kausatif tan 'buat' seperti yang tersaji pada klausa (19b)(24b).

Konstruksi kausatif analitik pada klausa tersebut dibangun oleh verba kausatif tau 'buat dengan verba transiitf, yaitu tana 'tanam' pada klausa (19b), ala 'beli' pada klausa (20b), ne 'beri' pada klausa (21b), leli 'tebang' pada klausa (22b), hoat 'angkat' pada klausa (23b), dan sali 'tangkap' pada klausa (24b). Hakikat pengkausatifan yang mengubah kluasa dengan verba transitif menjadi konstruksi kausatif analitik yang dibangun oleh verba kausatif tau 'buat' mengubah fungsi gramatikal subjek pada klausa transitif, yaitu au 'saya' pada klausa (19a), ua 'dia' pada klausa (20a), mane senua 'laki-laki itu' pada klausa (21a), ali 'adik' pada klausa (22a), ina 'ibu' pada klausa (23a), dan atmas senua 'orang itu' pada klausa (24a) menjadi fungsi gramatikal objek pada konstruksi kausatif analitik pada klausa (19b)(24b).

Telah diuraikan sebelumnya konstruksi kausatif yang dibangun oleh verba kausatif tau 'buat' dengan verba intransitif dan verba ekatransitif. Bagian berikutnya menguraikan konstruksi kausatif yang dibangun oleh verba kausatif tau 'buat' dengan predikat yang ditempati oleh adjektival. Untuk lebih jelasnya, perhatikan klausa-klausa di bawah ini.
a. Uma senua bderang rumah DEF bersih 'Rumah itu bersih'
b. Ina tau uma senua bderang ibu buat rumah DEF bersih 'Ibu membuat rumah itu bersih'

$\begin{array}{llr}\begin{array}{ll}\text { c. } \\ \text { uma }\end{array} & \begin{array}{l}\text { Ina tau } \\ \text { senua }\end{array} & \text { bderang } \\ \text { buat } & \text { bersih } & \text { ibu } \\ & \text { rumah DEF } \\ & \text { 'Ibu membuat bersih rumah }\end{array}$
itu'
a. Au-ng ahi boteng 1TG-Lig babi besar 'Babi saya besar'
b. Ina tau botengau-ng ahi ibu buat besar 1TG-

Lig babi 


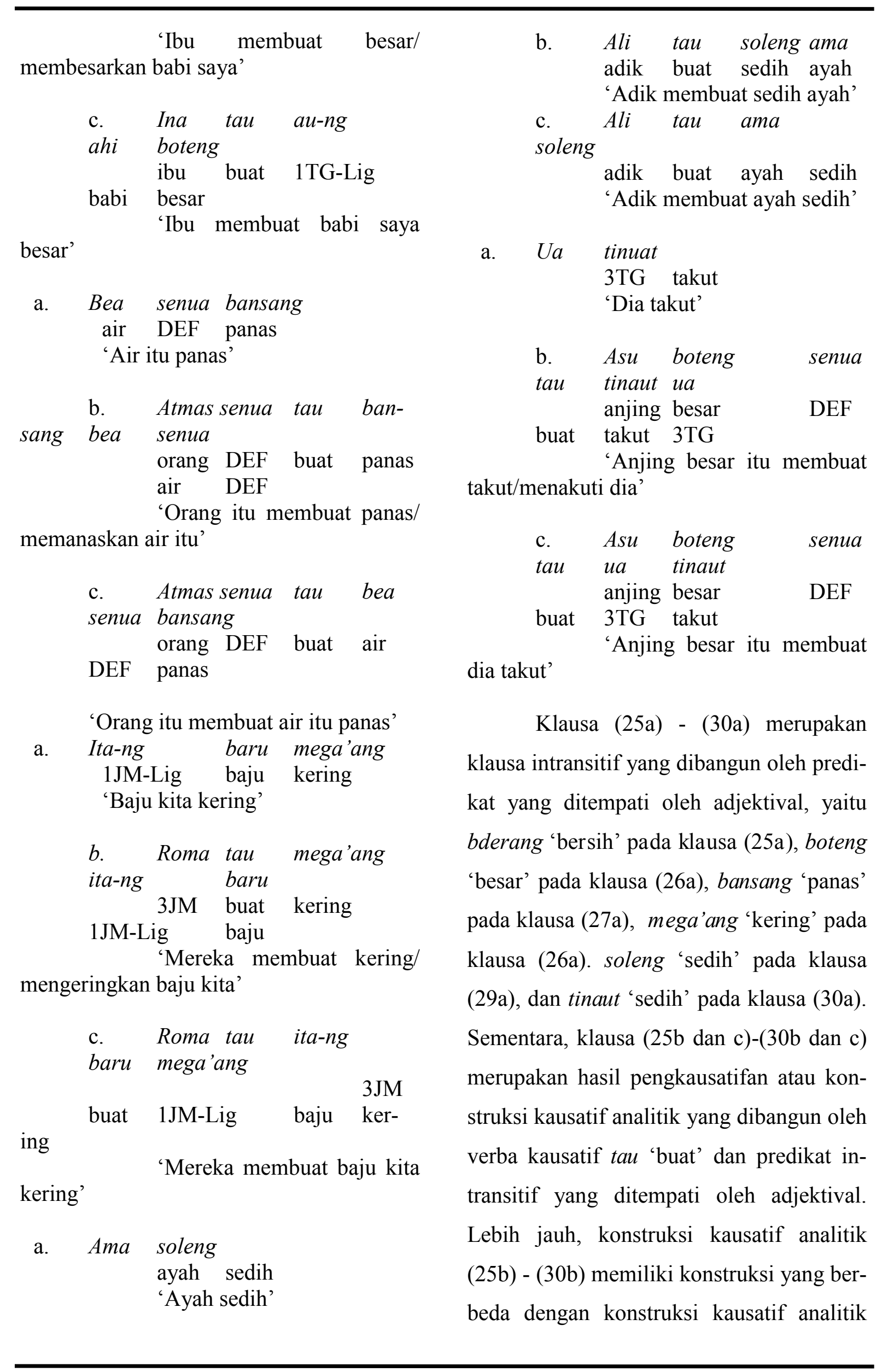


(25c) - (30c). Konstruksi kausatif analitik (25c) - (30c) merupakan konstruksi alternasi dari konstruksi kausatif analitik (25b) (30b). Namun, kedua konstruksi kausatif tersebut berterima secara gramatikal dalam BKm. Pada hakikatnya, pengkausatifan yang mengubah klausa intransitif dengan predikat adjektival menjadi konstruksi kausatif analitik yang dibangun oleh verba kausatif tau 'buat' dengan predikat intransitif yang diisi oleh adjektival, merubah fungsi gramatikal subjek pada klausa intransitif, yaitu uma senua 'rumah itu' pada klausa (25a), aung ahi 'babi saya' pada klausa (26a), bea senua 'air itu' pada klausa (27a), itang baru 'baju kita' pada klausa (28a), ama 'ayah' pada klausa (29a), dan $u a$ 'dia' pada klausa (30a) menjadi fungsi gramatikal objek pada konstruksi kausatif analitik pada klausa (25b dan c) (30b dan c).

Uraian di atas telah menjabarkan pengkausatifan atau konstruksi kausatif analitik yang dibentuk oleh verba kausatif tau 'buat' dengan verba intransitif, verba transitif, dan predikat yang diisi oleh adjektival. Selanjutnya akan diuraikan pengkausatifan atau konstruksi kausatif yang dibanrtuk oleh verba kausatif laka 'suruh' yang diikuti oleh verba intransitif dan verba transitif. Pada konstruksi kausatff dengan verba kausatif laka 'suruh', tidak dapat diikuti oleh predikat yang ditempati oleh adjektival. Untuk lebih jelasnya, berikut disajikan konstruksi kausatif yang dibentuk oleh verba kausatif laka 'suruh' dengan verba intransitif dan verba transitif.

Mane senua hali
laki-laki DEF pulang
'Laki-laki itu pulang'

$$
\begin{array}{lll}
\text { b. } & \text { Au-ng } & \multicolumn{2}{c}{\text { ama-ng }} \\
\text { laka } & \text { hali mane } & \text { senua } \\
& \text { 1TG-Lig ayah-Lig } \\
\text { suruh pulang laki-laki DEF } & \begin{array}{l}
\text { puah saya menyuruh pu- } \\
\text { 'Ayah saya }
\end{array}
\end{array}
$$$$
\text { lang laki-laki itu' }
$$

$$
\begin{array}{lll}
\text { c. } & \text { Au-ng } & \text { ama-ng } \\
\text { laka mane } & \text { senua hali } \\
& & \text { 1TG- }
\end{array}
$$

Lig ayah-Lig suruh laki-laki

DEF pulang laki itu pulang'

$$
\text { 'Ayah saya menyuruh laki- }
$$
Lig istri-Lig saya'
'Saya menyuruh tidur istri
b. Au laka bue Au-ng he-ng
1TG suruh tidur 1TG-

$$
\begin{array}{lll}
\begin{array}{l}
\text { c. Au laka } \\
\text { he-ng }
\end{array} & \begin{array}{l}
\text { bue } \\
\text { suruh } \\
\text { 1TG }
\end{array} & \begin{array}{l}
\text { suru-Lig } \\
\text { tidur }
\end{array}
\end{array}
$$

menyuruh istri saya tidur'

'Saya
a. Hine senua hnanu
wanita DEF nyanyi
'Wanita itu bernyanyi' 


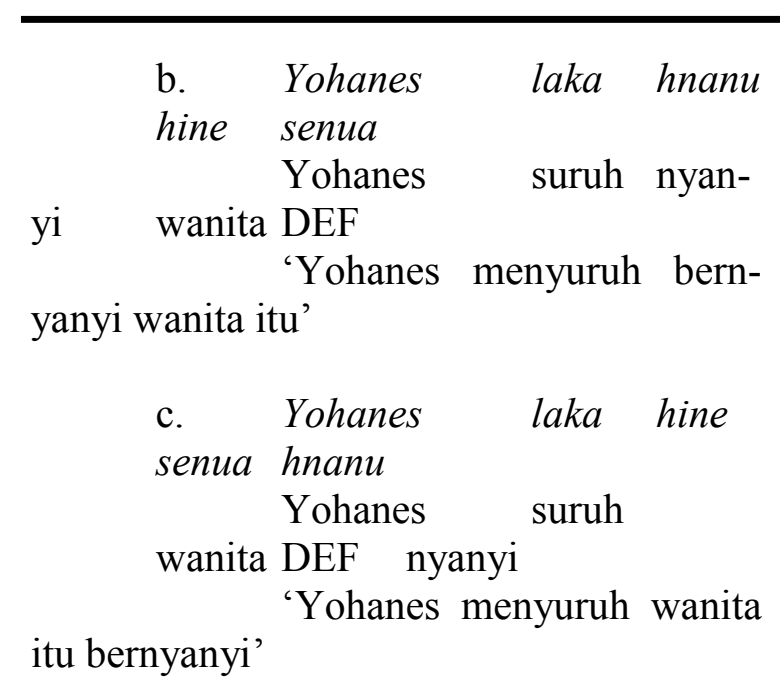

a. Ama la de isikola ayah pergi Prep sekolah

'Ayah pergi ke sekolah'

b. Guru laka la ama de isikola

Guru suruh pergi ayah Prep sekolah

'Guru menyuruh pergi ayah ke sekolah'
c. Guru laka ama la de isikola
Guru suruh ayah pergi
Prep sekolah
'Guru menyuruh

ayah pergi ke sekolah'

a. Maria ala kokis

Mariabeli kue

'Maria membeli kue'

b. Ina laka Maria ala

kokis

ibu suruh Maria beli

kue

'Ibu menyuruh Maria mem-

beli kua'

$\begin{array}{ccc}\text { a } & \text { Au pegegini } & \text { osa } \\ \text { 1TG pinjam uang } & \text { 'Saya meminjam uang' }\end{array}$

b. Ama laka au
pegegini
jam osa
ayah suruh 1TG pin-
uang
'Ayah menyuruh saya mem- injam uang'

a. Ali lotu uta

adik potong sayur

'Adik memotong sayur'

b. Ina laka ali lotu

uta

potong sayur

ibu suruh adik

'Ibu menyuruh adik memo-

tong sayur'

a. Ali hasa baru

Ali cuci baju

'Adik mencuci baju'

b. Ina laka ali hasa baru

Ibu suruh adik cuci baju

'Ibu menyuruh adik

emncuci baju'

Sama halnya dengan mekanisme pengkausatifan atau konstruksi kausatif analitik dengan verba kausatif tau 'buat', verba kausatif laka 'suruh' juga memiliki kemampuan untuk membentuk konstruksi kausatif analitik, seperti yang tersaji pada konstruksi kausatif (31b) - (38b). Klausa (31a) - (34a) adalah klausa yang dibangun oleh verba intransitif, sementara klausa (35a) - (38a) dibangun oleh verba transitif dalam BKm.

Verba intransitif dan transitif pada klausa (31a) - (38a) dapat pula membentuk konstruksi kauatif analitik apabila verba intransitif dan verba transitif tersebut didahului oleh verba kausatif laka 'suruh' seperti yang tersaji pada klausa (31b)-(38b). Konstruksi kausatif analitik pada klausa tersebut dibangun oleh verba kausatif laka 
'suruh' dengan verba intransitif, yaitu hali 'pulang' pada klausa (31b), bue 'tidur' pada klausa (32b), hananu 'nyanyi' pada klausa (33b), dan la 'pergi pada klausa (34b), dan dengan verba transitif, yaitu ala 'beli' pada klausa (35b), pegegini 'pinjam' pada klausa (36b), lotu 'potong' pada klausa (37b), dan hasa 'cuci' pada klausa $(38 b)$.

Pengkausatifan dengan verba kausatif laka 'suruh' mengubah kluasa dengan verba intransitif dan verba transitif menjadi konstruksi kausatif analitik, pada hakikatnya merngubah fungsi gramatikal subjek pada klausa dengan verba intransitif, yaitu mane senua 'laki-laki itu' pada klausa (31a), aung heng 'istri saya' pada klausa (32a), hine senua 'wanita itu' pada klausa (33a), dan ama 'ayah' pada klausa (34a) . Di samping itu, juga mengubah fungsi gramatikal subjek pada klausa dengan verba transitif, yaitu Maria 'Maria' pada klausa (35a), au 'saya' pada klausa (36a), ali 'adik' pada klausa (37a), dan ali 'adik' pada klausa (38a) menjadi fungsi gramatikal objek pada konstruksi kausatif analitik pada klausa (31b) - (38b).

\section{SIMPULAN}

Berdasarkan permasalahan yang dibahas terkait dengan konstruksi kausatif analitik BKm dapat ditarik beberapa simpulan sebagai berikut.

BKm hanya memiliki dua konstruksi kausatif, yaitu konstruksi kausatif leksikal dan kausatif analitik. Ketiadaan konstruksi kausatif morfologis dikarenakan tidak adanya afiks yang berfungsi merubah konstruksi non-kausatif menjadi konstruksi kausatif.

Terkait konstruksi kausatif, BKm memiliki bentuk verba ekatransitif dan verba intransitif yang berbeda, seperti verba pule 'mematahkan' dengan verba teta 'patah', verba, verba pae 'memasukkan' dengan verba mola 'masuk', verba tboa 'memecahkan' dengan verba broe 'pecah', verba lape 'menaikkan' dengan verba $d u$ 'naik', dan verba luida 'menurunkan' dengan verba sae 'turun'.

Kausatif analitik BKm dibangun oleh verba kausatif tau 'buat' dengan predikat yang diisi oleh verba intransitif, verba transitif, dan predikat adjektival.

Di samping konstruksi kausatif yang dibangun oleh verba kausatif tau 'buat', konstruksi kausatif BKm juga dapat dibentuk dengan bantuan verba kausatif laka 'suruh'. Pembentukan konstruksi kausatif analitik dengan verba laka 'suruh' hanya dapat diikuti oleh verba intransitif dan transitif dalam BKm.

Konstruksi kausatif BKm dengan verba intransitif dan verba transitif baik yang dibentuk dengan bantuan verba tau 'buat' dan laka 'suruh' memiliki bentuk alternasi. Bentuk alternasi ini disebabkan 
karena posisi objek pada konstruksi kausa-

tif analitik $\mathrm{BKm}$ bisa menempati posisi setelah verba kausatif. tau 'buat' dan laka 'suruh'laka dan dikuti oleh verba intransitid ataupun verba transitif dan bisa juga objek menempati posisi akhir konstruksi kausatif analitik.

\section{UCAPAN TERIMA KASIH}

Penulis mengucapkan terima kasih kepada Mitra Bestari atas masukanmasukan yang telah diberikan untuk perbaikan substansi artikel saya ini

\section{DAFTAR PUSTAKA}

Alsina, A. and Joshi, S. 1991. Parameters in Causative Constructions. Chicago Linguistics Society 27. Hal 2--16.

Arka, I Wayan. 1993. Morpholexical A spects of the-Kan Causative in Indonesia (tesis). Sydney: University of Sydney.

Artawa, Ketut. 2012. The Basic Verb Construction in Balinese. Dalam Alexander Adelaar (Ed.) Voice Variation in A ustronesian Language of Indonesia. NUSA 54, 5-27.

Budiarta, I Wayan. 2013. Tipologi Sintaksis Bahasa Kemak (disertasi). Denpasar: Program Pascasarjana Universitas Udayana.

Blake, Barry J. 1990. Relational Grammar. London : Routledge

Comrie, B. 1983, 1989. Language Universal and Linguistic Typology. Oxford : Basil Blackwell.

Goddard, Cliff. 1998. Semantic Analysis - A Practical Introduction. Oxford : Oxford University Press.

Kozinsky, Isaac., Polinsky, Maria. 1993. Causative and Patient in the Causative Transitive: Coding Conflict or Doubling of Grammatical Relations; Dalam : Comrie dan Polinsky (Ed.),.. Causative and Transitivity: $\quad 177-240 . \quad$ Amsterdam.Philadelphia: John Benjamin Pub- lishing Company.

Shibatani, Masayoshi (Ed.). 1976. Syntax and Semantic: The Grammar of Causative Construction. New York: Academic Press.

Shibatani, Masayoshi. 1996. Applicative and Benefactives. A Cognitive Acount. Dalam : Shibatani, Masayoshi dan Sandra A Thompson (ed.),.. Grammatical Construcstion: Their Form and Meaning: 157-194. Oxford : Clarendon Press.

Song, Jae Jung. 2001. Linguistic Typology: Morphology and Syntax. London: Longman.

Sudaryanto. 1986. Metode Linguistik. Yogyakarta: Gadjah Mada University Press.

Sudaryanto. 1993. Metode dan Aneka Teknik Analisis Bahasa. Yogyakarta: Duta Wacana University Press 